\title{
A New Synthesis of Triphenylphosphorane Ylide Precursors to a-Keto Amide/Ester and Tricarbonyl Units via Horner-Wadsworth-Emmons Reaction
}

\author{
Kieseung Lee \\ Department of Applied Chemistry,Woosuk University, Chonbuk 565-701,Korea.E-mail: kslee@woosuk.ac.kr \\ Received June 28, 2010, Accepted August 5, 2010
}

\begin{abstract}
Newly developed Horner-Wadsworth-Emmons (HWE) reagents $\mathbf{5}$ having triphenylphosphorane ylide subunits readily condensed with various carbonyl compounds under mild reaction conditions to afford $\beta, \gamma$-unsaturated $\alpha$-keto triphenylphorane ylides in good to excellent yields, which were hydrogenated over Pd-C $(10 \%) / \mathrm{H}_{2}(1 \mathrm{~atm})$ to give the corresponding $\alpha$-keto triphenylphorane ylides in quasi-quantitative yields. These triphenyphosphorane ylides have been utilized as the precursors to $\alpha$-keto amide/ester and vicinal tricarbonyl units in Wasserman's synthetic protocols, and have previously been prepared only from carboxylic acids/acid chlorides. Our new approaches provide excellent alternatives for the synthesis of triphenylphosphorane ylide precursors to $\alpha$-keto amide/ester and vicinal tricarbonyl units directly from carbonyl compounds in good to excellent yields.
\end{abstract}

Key Words: $\alpha$-Keto amide, $\alpha$-Keto ester, Vicinal tricarbonyl, Triphenylphosphorane ylide, Horner-WadsworthEmmons reaction

\section{Introduction}

The highly electrophilic structural fragments such as $\alpha$-keto amide/ester ${ }^{1}$ and vicinal tricarbonyl units ${ }^{2}$ have attracted considerable research interest in recent years since these units have been frequently found as the key structural fragments in many biologically important natural compounds e.g., FK-506, ${ }^{3 \mathrm{a}}$ rapamycin, ${ }^{3 \mathrm{~b}}$ cyclotheonamide ${ }^{3 \mathrm{c}}$ and eurystatin. ${ }^{3 \mathrm{~d}}$ Furthermore, these units have been shown to be extremely useful for the synthesis of various heterocyclic compounds, ${ }^{4}$ and also increasingly incorporated as the electrophilic ketone pharmacophores into synthetic molecules exhibiting inhibitory activities against certain enzymes. ${ }^{5}$

Thus there have been active research efforts to develop a new synthetic approach to these functionalities. ${ }^{6,7}$ Wasserman

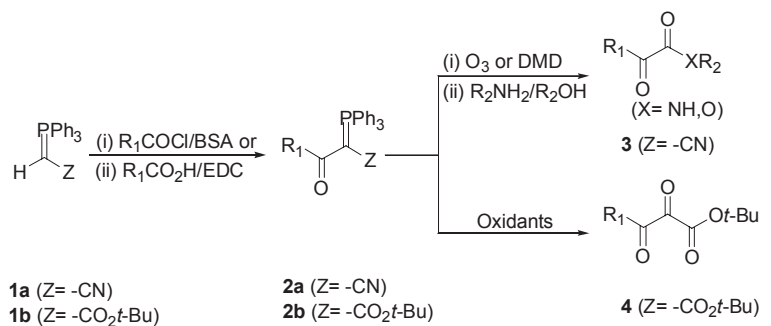

Scheme 1. Wasserman's synthetic route for $\alpha$-keto amide/ester and tricarbonyl units

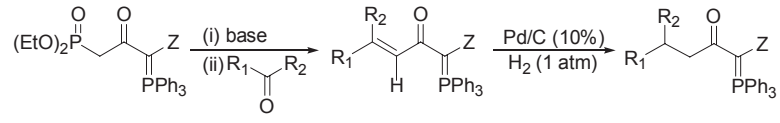

$$
\begin{aligned}
& \begin{array}{lll}
\mathbf{5} \mathbf{a}(\mathrm{Z}=-\mathrm{CN}) & \mathbf{6 a}(\mathrm{Z}=-\mathrm{CN}) & \mathbf{2 a}(\mathrm{Z}=-\mathrm{CN}) \\
\mathbf{5} \mathbf{b}\left(\mathrm{Z}=-\mathrm{CO}_{2} t-\mathrm{Bu}\right) & \mathbf{6 b}\left(\mathrm{Z}=-\mathrm{CO}_{2} t-\mathrm{Bu}\right) & \mathbf{2 b}\left(\mathrm{Z}=-\mathrm{CO}_{2} t-\mathrm{B} t\right)
\end{array}
\end{aligned}
$$

Scheme 2. A new synthesis of triphenylphosphorane ylide precursors $\mathbf{6} \& \mathbf{2}$ from carbonyl compounds utilizing new HWE reagents $\mathbf{5 a} \& \mathbf{5 b}$ et al. reported elegant synthetic routes for these units based on the phosphorane ylide chemistry in which the key intermediates $\mathbf{2}$ were converted to the target molecules under mild reaction conditions in a convergent manner (Scheme 1). ${ }^{8}$

These approaches have been widely employed in the synthesis of a variety of complex molecules having $\alpha$-keto amide/ ester or vicinal tricarbonyl unit. ${ }^{9}$ However, there is a limitation that the key intermediates $\mathbf{2}$ can be derived only from carboxylic acids or acid chlorides. In order to circumvent this limitation, we recently developed a new synthetic approach to triphenylphosphorane ylides (6a, 2a) utilizing a new Horner-WadsworthEmmons $(\mathrm{HWE})^{10}$ reagent $\mathbf{5} \mathbf{a}$ as the key reagent (Scheme 2, Z = $-\mathrm{CN}){ }^{11}$

In continuation of our study in this area of chemistry, ${ }^{9 c, 9 e, 11,12}$ we have done a thorough study of this new approach by using different bases/various carbonyl compounds, and also extended the same approach for the synthesis of triphenylphosphorane ylide precursors $(\mathbf{6 b}, \mathbf{2 b})$ to vicinal tricarbonyl unit (Scheme 2, $\left.\mathrm{Z}=-\mathrm{CO}_{2} t-\mathrm{Bu}\right)$. Herein, we wish to report the details of this new study and data of the reaction products.

\section{Results and Discussion}

The success of this new approach depends overwhelmingly upon the successful synthesis of the new HWE reagent 5a from the cheap and easily available materials via reliable procedures. Thus, we first examined the two-step route described in Scheme 3: the commercially available reagents, chloroacetyl chloride (7) and cyanophosphorane 1a, were coupled in the presence of BSA to give the intermediate $\mathbf{8}^{13}$ which was heated in $\mathrm{P}(\mathrm{OEt})_{3}$ $\left(110{ }^{\circ} \mathrm{C}, 24 \mathrm{~h}, \mathrm{Ar}\right)$ to afford the requisite HWE reagent $\mathbf{5 a}$ in $78 \%$ overall yield. ${ }^{11}$

This two-step route, however, suffers from using the highly unstable reagent 7 and also requiring tedious chromatographic separation of the intermediate $\mathbf{8}$. Therefore, we devised onestep route starting from the commercially available reagents, 
diethylphosphonoacetic acid (9) and cyanophosphorane 1a, using EDC as a coupling reagent, and new HWE reagent 5a was obtained as an analytically pure crystalline solid in $81 \%$ yield by recrystallization of the reaction mixture from EtOAc. ${ }^{9 e, 12}$

With the key reagent 5a in hand, various carbonyl compounds were reacted with $\mathbf{5 a}$ using $\mathrm{NaH}$ as the first choice of base (Table 1).

The deprotonation of $5 \mathbf{a}$ with $\mathrm{NaH}$ (1.3 eq) took place smoothly at $\mathrm{rt}$ in $20 \mathrm{~min}$ to afford the stabilized enolate which was reacted with a number of carbonyl compounds under mild conditions. Reactions of simple aryl/aliphatic aldehydes with $\mathbf{5 a}$ under the standard conditions afforded exclusively $(E)$-olefins in excellent yields (runs 1, 4, and 5). Sterically hindered aldehydes such as 2,6-dimethylbenzaldehyde, however, required

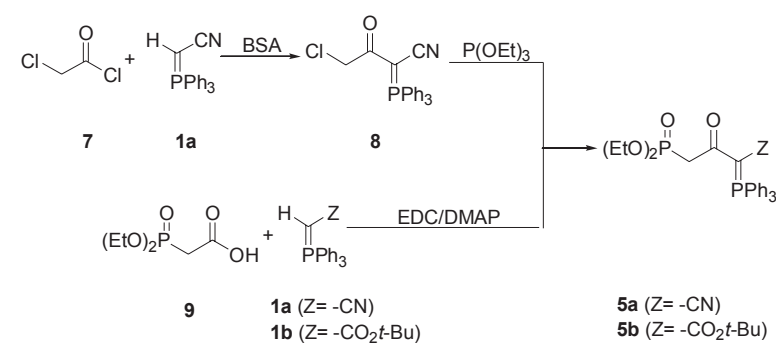

Scheme 3. Attempted synthesis of new HWE reagents $\mathbf{5 a} \& \mathbf{5 b}$ longer reaction time (runs 2 and 3). The reaction of $\mathrm{N}$-BOC2-aminoacetaldehyde with $\mathbf{5 a}$ draws special attention since it could afford $\gamma$-aminobutyric acid (GABA)-derived $\alpha$-keto amide/ester units incorporated in bioactive compounds (run 6). ${ }^{14}$ trans-Cinnamaldehyde also readily condensed with 5a under the standard conditions to give ylide 6a.7 in good yield (run 7). Considering the compounds with heteroaromatic units exhibiting biological activities, it is of special interest to efficiently synthesize triphenylphosphorane ylides with heteroaromatic moieties. 2-Furaldehyde and 2-thiophenecarboxaldehyde reacted readily with $\mathbf{5} \mathbf{a}$ under the standard conditions to provide the corresponding ylides (6a.8 and 6a.9) in good yields (runs 8 and 9).

We also tested ketones for this reaction. The reaction of ketones with $\mathbf{5 a}$ under the standard conditions, however, was confirmed to be sluggish and incomplete: 3-pentanone afforded ylide $\mathbf{6 a . 1 0}$ in $41 \%$ yield, and benzophenone gave ylide $\mathbf{6 a . 1 1}$ in $58 \%$ yield even stirring the reaction mixture for $24 \mathrm{~h}$ and 22 $\mathrm{h}$ respectively (runs 10 and 11).

Next, we turned our attention to BuLi as base. The deprotonation of $\mathbf{5 a}$ with BuLi (1.1 eq) was readily accomplished at $-78{ }^{\circ} \mathrm{C}$ in $15 \mathrm{~min}$, and condensation of the resulting enolate with representative aldehydes were completed in $2 \mathrm{~h}$ in good to excellent yields (runs 12 - 17). In general, BuLi appears to be better than $\mathrm{NaH}$ in terms of yields and the mildness of the

Table 1. Condensation of $\mathbf{5 a}$ with carbonyl compounds and subsequent hydrogenation of $\mathbf{6 a}$ to $\mathbf{2 a}$ over Pd-C $(10 \%) / \mathrm{H}_{2}(1 \mathrm{~atm})$

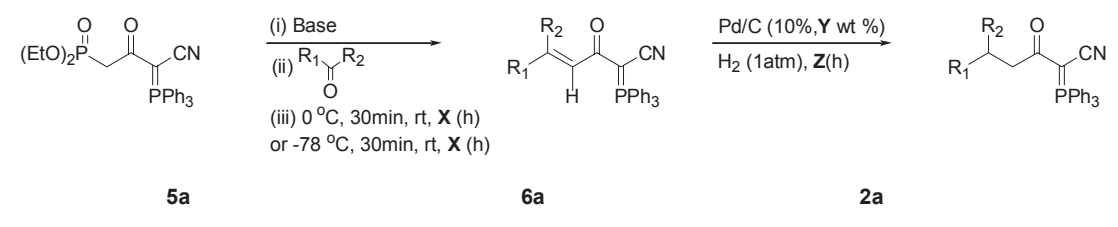

\begin{tabular}{|c|c|c|c|c|c|c|c|c|c|}
\hline Run & $\mathrm{R}_{1}$ & $\mathrm{R}_{2}$ & Base & $\mathbf{X}(\mathrm{h})$ & $\begin{array}{c}\mathbf{6 a} \\
(\text { Yield, \%) }\end{array}$ & Run & $\mathbf{Y}(\mathrm{wt} \%)$ & $\mathbf{Z}(\mathrm{h})$ & $\begin{array}{c}\mathbf{2 a} \\
(\text { Yield, \%) }\end{array}$ \\
\hline 1 & $\mathrm{Ph}-$ & $\mathrm{H}$ & $\mathrm{NaH}$ & 1 & $\mathbf{6 a . 1}(93)^{b}$ & $1^{\prime}$ & 10 & 3 & $\mathbf{2 a . 1}(98)^{e}$ \\
\hline 2 & 2-MePh- & $\mathrm{H}$ & $\mathrm{NaH}$ & 3 & $\mathbf{6 a . 2}(91)^{c}$ & $2^{\prime}$ & 10 & 10 & 2a.2 $(97)^{e}$ \\
\hline 3 & $2,6-(\mathrm{Me}){ }_{2} \mathrm{Ph}-$ & $\mathrm{H}$ & $\mathrm{NaH}$ & 22 & $\mathbf{6 a . 3}(87)^{c}$ & $3^{\prime}$ & 30 & 24 & 2a.3 $(95)^{e}$ \\
\hline 4 & $\mathrm{Ph}\left(\mathrm{CH}_{2}\right)_{2^{-}}$ & $\mathrm{H}$ & $\mathrm{NaH}$ & 1 & $\mathbf{6 a . 4}(89)^{c}$ & $4^{\prime}$ & 10 & 3 & $\mathbf{2 a . 4}(98)^{e}$ \\
\hline 5 & $\mathrm{CH}_{3}\left(\mathrm{CH}_{2}\right)_{6^{-}}$ & $\mathrm{H}$ & $\mathrm{NaH}$ & 1 & $\mathbf{6 a . 5}(88)^{c}$ & $5^{\prime}$ & 10 & 3 & $\mathbf{2 a . 5}(97)^{e}$ \\
\hline 6 & $\mathrm{BOCNHCH}_{2-}$ & $\mathrm{H}$ & $\mathrm{NaH}$ & 1 & $\mathbf{6 a . 6}(89)^{c}$ & $6^{\prime}$ & 10 & 3 & $2 \mathbf{a . 6}(91)^{e}$ \\
\hline 7 & $\mathrm{PhCH}=\mathrm{CH}-$ & $\mathrm{H}$ & $\mathrm{NaH}$ & 1 & 6a.7 $(78)^{c}$ & - & - & - & $\mathrm{NA}^{f}$ \\
\hline 8 & 2-Furanyl & $\mathrm{H}$ & $\mathrm{NaH}$ & 3 & $\mathbf{6 a . 8}(87)^{c}$ & $7^{\prime}$ & 30 & 6 & $\mathbf{2 a . 7}(73)^{a}$ \\
\hline 9 & 2-Thiophenyl & $\mathrm{H}$ & $\mathrm{NaH}$ & 3 & $\mathbf{6 a . 9}(81)^{c}$ & $8^{\prime}$ & 50 & 24 & $\mathrm{ND}^{g}$ \\
\hline 10 & Et- & Et- & $\mathrm{NaH}$ & 24 & $6 \mathbf{6 . 1 0}(41)^{c, d}$ & $9^{\prime}$ & 30 & 16 & $\mathbf{2 a . 8}(98)^{e}$ \\
\hline 11 & $\mathrm{Ph}-$ & $\mathrm{Ph}-$ & $\mathrm{NaH}$ & 22 & 6a.11 (58) & $10^{\prime}$ & 30 & 6 & 2a.9 $(99)^{e}$ \\
\hline 12 & $\mathrm{Ph}-$ & $\mathrm{H}$ & $\mathrm{BuLi}$ & 2 & $\mathbf{6 a . 1}(94)^{b}$ & - & - & - & - \\
\hline 13 & $\mathrm{CH}_{3}\left(\mathrm{CH}_{2}\right)_{6^{-}}$ & $\mathrm{H}$ & $\mathrm{BuLi}$ & 2 & $\mathbf{6 a . 5}(89)^{c}$ & - & - & - & - \\
\hline 14 & $\mathrm{BOCNHCH}_{2-}$ & $\mathrm{H}$ & $\mathrm{BuLi}$ & 2 & $\mathbf{6 a . 6}(95)^{c}$ & - & - & - & - \\
\hline 15 & $\mathrm{PhCH}=\mathrm{CH}-$ & $\mathrm{H}$ & $\mathrm{BuLi}$ & 2 & 6a.7 $(90)^{c}$ & - & - & - & - \\
\hline 16 & 2-Furanyl & $\mathrm{H}$ & $\mathrm{BuLi}$ & 2 & $\mathbf{6 a . 8}(92)^{c}$ & - & - & - & - \\
\hline 17 & 2-Thiophenyl & $\mathrm{H}$ & $\mathrm{BuLi}$ & 2 & $6 \mathbf{6 . 9}(93)^{c}$ & - & - & - & - \\
\hline
\end{tabular}

${ }^{a}$ Isolated yield after flash chromatography; ${ }^{b}(E)$-Stereochemistry was unambiguously confirmed by comparing mp, ${ }^{\mathrm{I}} \mathrm{R}, 1 \mathrm{H} \&{ }^{13} \mathrm{C} \mathrm{NMR}$ of $6 \mathbf{6 . 1}$ with those of the same product prepared from trans-cinnamic acid; ${ }^{c}(E)$-Stereochemistry was confirmed by coupling const. (ca. $\left.15-16 \mathrm{~Hz}\right)$ between two vinylic protons; ${ }^{d} \mathbf{5 a}$ was recovered in $50 \%$ \& $37 \%$ yield; ${ }^{e}$ Isolated yield after filtering, washing the filtered-cake \& drying in vacuo; Not attempted; ${ }^{g}$ Not determined the yield of each rxn mixture. 
Table 2. Condensation of $\mathbf{5 b}$ with carbonyl compounds and subsequent hydrogenation of $\mathbf{6} \mathbf{b}$ to $\mathbf{2} \mathbf{b}$ over Pd-C $(10 \%) / \mathrm{H}_{2}(1 \mathrm{~atm})$

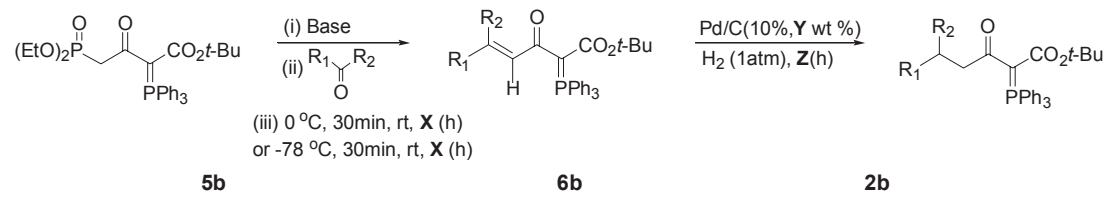

\begin{tabular}{|c|c|c|c|c|c|c|c|c|c|}
\hline Run & $\mathrm{R}_{1}$ & $\mathrm{R}_{2}$ & Base & $\mathbf{X}(\mathrm{h})$ & $\begin{array}{c}\mathbf{6 a} \\
(\text { Yield, \%) }\end{array}$ & Run & $Y($ wt \%) & $\mathbf{Z}$ (h) & $\begin{array}{c}\mathbf{2 a} \\
(\text { Yield, \%) }\end{array}$ \\
\hline 1 & $\mathrm{Ph}-$ & $\mathrm{H}$ & $\mathrm{NaH}$ & 1 & 6b.1 $(86)^{b}$ & $1^{\prime}$ & 15 & 5 & $\mathbf{2 b . 1}(98)^{c}$ \\
\hline 2 & $\mathrm{CH}_{3}\left(\mathrm{CH}_{2}\right)_{6^{-}}$ & $\mathrm{H}$ & $\mathrm{NaH}$ & 1 & 6b.2 $(83)^{b}$ & $2^{\prime}$ & 15 & 5 & $\mathbf{2 b . 2}(99)^{c}$ \\
\hline 3 & $\mathrm{BOCNHCH}_{2-}$ & $\mathrm{H}$ & $\mathrm{NaH}$ & 1 & 6b.3 $(89)^{b}$ & $3^{\prime}$ & 15 & 5 & $\mathbf{2 b . 3}(95)^{c}$ \\
\hline 4 & $\mathrm{PhCH}=\mathrm{CH}-$ & $\mathrm{H}$ & $\mathrm{NaH}$ & 1 & $\mathbf{6 b . 4}(87)^{b}$ & - & - & - & $\mathrm{NA}^{d}$ \\
\hline 5 & 2-Furanyl & $\mathrm{H}$ & $\mathrm{NaH}$ & 1 & $\mathbf{6 b . 5}(88)^{b}$ & $4^{\prime}$ & 30 & 10 & 2b.4 $(81)^{a}$ \\
\hline 6 & 2-Thiophenyl & $\mathrm{H}$ & $\mathrm{NaH}$ & 1 & 6b.6 $(76)^{b}$ & $5^{\prime}$ & 50 & 24 & $\mathrm{ND}^{e}$ \\
\hline 7 & $\mathrm{Ph}-$ & $\mathrm{H}$ & $\mathrm{BuLi}$ & 2 & 6b.1 $(94)^{b}$ & - & - & - & - \\
\hline 8 & $\mathrm{CH}_{3}\left(\mathrm{CH}_{2}\right)_{6^{-}}$ & $\mathrm{H}$ & $\mathrm{BuLi}$ & 2 & 6b.2 $(94)^{b}$ & - & - & - & - \\
\hline 9 & $\mathrm{BOCNHCH}_{2-}$ & $\mathrm{H}$ & $\mathrm{BuLi}$ & 2 & 6b.3 $(96)^{b}$ & - & - & - & - \\
\hline 10 & $\mathrm{PhCH}=\mathrm{CH}-$ & $\mathrm{H}$ & $\mathrm{BuLi}$ & 2 & $\mathbf{6 b . 4}(90)^{b}$ & - & - & - & - \\
\hline 11 & 2-Furanyl & $\mathrm{H}$ & $\mathrm{BuLi}$ & 2 & 6b.5 $(95)^{b}$ & - & - & - & - \\
\hline 12 & 2-Thiophenyl & $\mathrm{H}$ & $\mathrm{BuLi}$ & 2 & 6b.6 $(97)^{b}$ & - & - & - & - \\
\hline
\end{tabular}

${ }^{a}$ Isolated yield after flash chromatography; ${ }^{b}(E)$-Stereochemistry was confirmed by coupling const. (ca. 15 - $16 \mathrm{~Hz}$ ) between two vinylic protons; ${ }^{c}$ Isolated yield after filtering, washing the filtered-cake \& drying in vacuo; ${ }^{d}$ Not attempted; ${ }^{c}$ Not determined the yield of each rxn mixture.

reaction conditions.

In order to convert $\mathbf{6 a}$ to $\mathbf{2 a}$, the normal catalytic hydrogenation protocol using $\mathrm{Pd}-\mathrm{C}(10 \%) / \mathrm{H}_{2}(1 \mathrm{~atm})$ has been adopted. The hydrogenation reaction proceeded very well in most cases simply by stirring the slurry of $\mathbf{6 a}$ and $\mathrm{Pd}-\mathrm{C}(10 \%)$ in a mixed solvent (THF/MeOH, 1/1) under $\mathrm{H}_{2}$ (1 atm) using balloon. Simple aryl/aliphatic/ $\alpha$-aminoacetaldehyde-derived phosphorane ylides were hydrogenated completely in $3 \mathrm{~h}$ with $\mathrm{Pd}-\mathrm{C}$ $(10 \%, 10$ wt \%) (runs 1', 4'-6'). Sterically hindered aryl aldehyde/ketone-based phosphorane ylides, however, required longer reaction time and higher loading of $\mathrm{Pd}-\mathrm{C}(10 \%, 30 \mathrm{wt} \%)$ for complete hydrogenation (runs 2'-3', 9'-10'). No detectable byproducts were formed (confirmed by TLC and ${ }^{1} \mathrm{H}$ NMR), which signifies that cyano- and triphenylphosphorane subunits are stable under this hydrogenation conditions. Therefore, simple filtration and removal of the solvent provided pure triphenylphosphorane ylides $\mathbf{2 a}$ in almost quantitative yields. On the other hand, 2-furaldehyde-derived phosphorane ylide $\mathbf{6 a . 8}$ needed higher loading of Pd-C (10\%, $30 \mathrm{wt} \%)$ and extended stirring time of $6 \mathrm{~h}$ for complete hydrogenation with simultaneous formation of two minor byproducts which apparently arise from hydrogenation of the furan ring (run 7'). Thiophenederived phosphorane ylide $6 \mathbf{6 . 9}$ is especially noteworthy since this ylide was confirmed to be highly resistant to hydrogenation. Even stirring the solution of $\mathbf{6 a . 9}$ with much higher loading of Pd-C (10\%, $50 \mathrm{wt} \%)$ for $24 \mathrm{~h}$, the reaction was incomplete and also gave significant amounts of two byproducts most probably due to the poisoning effect of sulfur atom on Pdcatalyst (run 8').

Stimulated by the successful results of HWE reagent 5a, we decided to try this new approach for the synthesis of triphenylphosphorane ylide precursors to vicinal tricarbonyl unit
(Scheme 2, $\mathrm{Z}=-\mathrm{CO}_{2} t$-Bu). The requisite new HWE reagent 5b was also prepared directly from diethylphosphonoacetic acid (9) and the commercially available phosphorane $\mathbf{1 b}$ in the presence of EDC in $86 \%$ yield (Scheme $3, \mathrm{Z}=-\mathrm{CO}_{2} t-\mathrm{Bu}$ ).

For the deprotonation of $\mathbf{5 b}$, both bases of $\mathrm{NaH}$ and BuLi were also utilized, and the resulting enolate was reacted with representative aldehydes under the similar conditions as for 5a (Table 2).

In general, the enolate of $\mathbf{5 b}$ readily condensed with aldehydes under the standard conditions to provide the corresponding ylides $\mathbf{6 b}$ in good to excellent yields (runs 1 - 12).

For the conversion of $\mathbf{6 b}$ to $\mathbf{2 b}$, the same catalytic hydrogenation protocol using $\mathrm{Pd}-\mathrm{C}(10 \%) / \mathrm{H}_{2}$ (1 atm) was also employed. Generally, phosphorane ylides $\mathbf{6 b}$ required a little more loading of Pd-C (10\%) and longer reaction time than ylides 6 a for complete hydrogenation. No detectable byproducts were formed during this hydrogenation step, thus, simple filtration and concentration in vacuo without chromatography afforded pure triphenylphosphorane ylides $\mathbf{2 b}$ in almost quantitative yields (runs 1'-3'). 2-Furaldehyde-derived ylide 6b.4 and thiophenederived ylide $6 \mathbf{b . 5}$ have shown the same reaction patterns as for $\mathbf{6 a . 8}$ and $\mathbf{6 a . 9}$ in hydrogenation. In the case of ylide $\mathbf{6 b . 4}$, the reaction proceeded fairly well with formation of two minor byproducts (run 4'). However, the hydrogenation of ylide $\mathbf{6 b . 5}$ was incomplete even with much higher loading of Pd-C (10\%, $50 \mathrm{wt} \%$ ) for prolonged reaction time of $24 \mathrm{~h}$, and also afforded significant amounts of byproducts (run 5').

\section{Experimental Section}

All reactions were carried out in oven-dried glassware under argon atmosphere. Melting points were determined on an Elec- 
trothermal melting-point apparatus and were uncorrected. FT IR spectra were obtained on Jasco FT-IR/410 using KBr. ${ }^{1} \mathrm{H}$ $(400 / 600 \mathrm{MHz})$ and ${ }^{13} \mathrm{C}$ NMR $(100 / 150 \mathrm{MHz})$ spectra were recorded on Jeol JNM-EX400 or JNM-ECA600 FT NMR spectrometer using $\mathrm{CDCl}_{3}$ as solvent, and chemical shifts $(\delta)$ are given in ppm downfield with respect to tetramethylsilane or the solvent as an internal standard. Mass spectra were measured with VG Autospec Ultima instrument in EI $(70 \mathrm{eV})$ mode or with micrOTOF-Q in ESI mode. CHN analyses were done with Vario EL elemental analyzer. Flash column chromatography was carried out on silica gel (Merck, 230 - 400 mesh) and solvents were reported as $\mathrm{V} / \mathrm{V}$ ratio mixture. THF was purified by distillation from $\mathrm{Na}$ /benzophenone. $\mathrm{N}, \mathrm{O}$-Bis(trimethylsilyl)aceamide (BSA), 1-[3-(dimethylamino)propyl]-3-ethylcarbodiimide $\mathrm{HCl}$ (EDC), (tert-butoxycarbonylmethylene)triphenylphosphorane, (triphenylphosphoranylidene)acetonitrile and diethylphosphonoacetic acid were purchased from Aldrich Chem. Co., and used directly without further purification. BuLi (2.5 $\mathrm{M}$ in THF) and $\mathrm{NaH}(60 \%$ in mineral oil) were purchased from Aldrich Chem. Co., and used directly without titration. 4-Dimethylaminopyridine (DMAP) and other commercial reagents were purchased from commercial sources and used as received unless otherwise stated.

Synthesis of HWE Reagent 5 a from chloroacetyl chloride (7). (i) To a stirred, precooled $\left(0{ }^{\circ} \mathrm{C}\right)$ solution of (triphenylphosphoranylidene)acetonitrile $(2.59 \mathrm{~g}, 8.60 \mathrm{mmol})$ in dry $\mathrm{CH}_{2} \mathrm{Cl}_{2}$ (30 mL) were added BSA (2.55 mL, $1.20 \mathrm{eq})$ and chloroacetyl chloride $(0.69 \mathrm{~mL}, 1.0 \mathrm{eq})$ by syringe, and the resulting solution was stirred at $0^{\circ} \mathrm{C}$ for $1 \mathrm{~h}$, and then at $\mathrm{rt}$ for $10 \mathrm{~h}$ under Ar. The reaction was quenched by the addition of $\mathrm{H}_{2} \mathrm{O}(20 \mathrm{~mL})$, and the organic layer was separated. The aqueous layer was extracted with $\mathrm{CH}_{2} \mathrm{Cl}_{2}(10 \mathrm{~mL} \times 2)$, and the combined organic layers were dried over $\mathrm{MgSO}_{4}$, filtered, and concentrated. The residue was purified by flash chromatography $\left(\mathrm{SiO}_{2}, \mathrm{CH}_{2} \mathrm{Cl}_{2} /\right.$ EtOAc, 20/1) to afford $\mathbf{8}(2.66 \mathrm{~g}, 82 \%)$ as a pale-brown solid. mp 185 - $187{ }^{\circ} \mathrm{C}$; IR (KBr) 2180, $1594 \mathrm{~cm}^{-1}$; ${ }_{1}^{1} \mathrm{HNMR}\left(\mathrm{CDCl}_{3}\right.$, $400 \mathrm{MHz}) \delta 4.44$ (s, 2H), 7.50-7.71 (m, 15H); ${ }^{13} \mathrm{C} \mathrm{NMR}\left(\mathrm{CDCl}_{3}\right.$, $100 \mathrm{MHz}) \delta 46.45,46.55,47.20,48.45,121.11,121.26,121.89$, $122.82,129.22,129.35,133.41,133.44,133.58,133.68,187.64$, 187.68. (ii) A mixture of $8(2.20 \mathrm{~g}, 5.83 \mathrm{mmol})$ in triethyl phosphite $(10 \mathrm{~mL})$ was heated at $110^{\circ} \mathrm{C}$ for $24 \mathrm{~h}$ under Ar. Removal of triethyl phosphite under high vacuum afforded the solid residue which was recrystallized from EtOAc $(60 \mathrm{~mL})$ to give $\mathbf{5 a}(2.50 \mathrm{~g})$ as a white solid. Additional crop $(0.15 \mathrm{~g})$ of $\mathbf{5 a}$ from the filtrate gave the total yield $(2.65 \mathrm{~g}, 95 \%)$. mp $180-182{ }^{\circ} \mathrm{C}$; IR ( $\mathrm{KBr}) 3057,2982,2173,1586,1249 \mathrm{~cm}^{-1} ;{ }^{1} \mathrm{H} \mathrm{NMR}\left(\mathrm{CDCl}_{3}\right.$, $400 \mathrm{MHz}) \delta 1.31(\mathrm{t}, 6 \mathrm{H}, J=7.1 \mathrm{~Hz}), 3.37(\mathrm{~d}, 2 \mathrm{H}, J=22.0 \mathrm{~Hz})$, 4.16 (m, 4H), 7.49-7.57 (m, 6H), 7.60-7.71 (m, 9H); ${ }^{13} \mathrm{C} \mathrm{NMR}$ $\left(\mathrm{CDCl}_{3}, 100 \mathrm{MHz}\right) \delta 16.32,16.37,37.75,37.82,39.04,39.11$, $50.34,50.39,51.60,51.65,62.13,62.19,121.84,122.00,122.33$, 123.26, 129.03, 129.16, 133.11, 133.14, 133.59, 133.70, 186.81, 186.86, 186.87, 186.92; HR-MS (EI) calcd for $\mathrm{C}_{26} \mathrm{H}_{27} \mathrm{NO}_{4} \mathrm{P}_{2}$ 479.1415, found 479.1412; Anal. calcd for $\mathrm{C}_{26} \mathrm{H}_{27} \mathrm{NO}_{4} \mathrm{P}_{2}$ : C, $65.13 ; \mathrm{H}, 5.68$; N, 2.92. found: C, 65.36; H, 5.67; N, 2.96.

Synthesis of HWE Reagent 5a from diethylphosphonoacetic acid (9). To a stirred solution of diethylphosphonoacetic acid (1.40 g, 95\%, $6.78 \mathrm{mmol}$ ) and (triphenylphosphoranylidene) acetonitrile $(2.11 \mathrm{~g}, 97 \%)$ in dry $\mathrm{CH}_{2} \mathrm{Cl}_{2}(30 \mathrm{~mL})$ were added
EDC (1.30 g, 98\%) and DMAP(0.13 g, 99\%), and the resulting mixture was stirred at $\mathrm{rt}$ for $12 \mathrm{~h}$ under Ar. The reaction was quenched by the addition of dil. $\mathrm{HCl}(20 \mathrm{~mL}, 0.1 \mathrm{~N})$, and the organic layer was separated. The aqueous layer was extracted with $\mathrm{CH}_{2} \mathrm{Cl}_{2}(10 \mathrm{~mL} \times 2)$, and the combined organic layers were dried over $\mathrm{MgSO}_{4}$, filtered, and concentrated. The solid residue was recrystallized from EtOAc $(50 \mathrm{~mL})$ to give $\mathbf{5 a}(2.64 \mathrm{~g}$, $81 \%$ ) as a colorless crystalline solid. Melting point and other spectroscopic data of this product were exactly matched with those of the same product prepared from chloroacetyl chloride.

General procedure for 6a using $\mathbf{N a H}$ as base. $\mathrm{NaH}(26.1 \mathrm{mg}$, $60 \%$ in oil, $1.3 \mathrm{eq})$ was added to a stirred solution of $\mathbf{5 a}(240.0$ $\mathrm{mg}, 0.50 \mathrm{mmol})$ in THF $(15 \mathrm{~mL})$, and the resulting mixture was stirred at $\mathrm{rt}$ for $20 \mathrm{~min}$, and then at $0{ }^{\circ} \mathrm{C}$ for $20 \mathrm{~min}$ under Ar. To this mixture was added benzaldehyde $(50.8 \mu \mathrm{L}, 1.0 \mathrm{eq})$ by syringe, and the resulting mixture was stirred at $0{ }^{\circ} \mathrm{C}$ for 30 $\mathrm{min}$, and then at $\mathrm{rt}$ for $1 \mathrm{~h}$ under Ar. The reaction was quenched by the addition of $\mathrm{H}_{2} \mathrm{O}(10 \mathrm{~mL})$, and the product was extracted with $\mathrm{CH}_{2} \mathrm{Cl}_{2}(20 \mathrm{~mL})$. The aqueous layer was extracted with $\mathrm{CH}_{2} \mathrm{Cl}_{2}(10 \mathrm{~mL} \times 2)$, and the combined organic layers were dried over $\mathrm{MgSO}_{4}$, filtered, and concentrated. The residue was purified by flash chromatography $\left(\mathrm{SiO}_{2}, \mathrm{CH}_{2} \mathrm{Cl}_{2} / \mathrm{Et}_{2} \mathrm{O}, 20 / 1\right)$ to afford 6a.1 (201.0 mg, 93\%) as a pale-yellow solid; mp 232 $234{ }^{\circ} \mathrm{C}$; IR (KBr) 2172, $1636 \mathrm{~cm}^{-1} ;{ }^{1} \mathrm{HNMR}\left(\mathrm{CDCl}_{3}, 400 \mathrm{MHz}\right)$ $\delta$ 7.28-7.38 (m, 3H), 7.43-7.60 (m, 10H), 7.61-7.71 (m, 9H); ${ }^{13} \mathrm{C} \mathrm{NMR}\left(\mathrm{CDCl}_{3}, 100 \mathrm{MHz}\right) \delta 50.28,51.55,122.00,122.16$, $122.76,123.64,123.69,123.73,128.14,128.62,129.10,129.22$, 129.34, 133.07, 133.11, 133.58, 133.67, 135.43, 138.94, 185.79, 185. 82; HR-MS (EI) calcd for $\mathrm{C}_{29} \mathrm{H}_{22} \mathrm{NOP} 431.1439$, found 431.1430 .

General procedure for 6 a using $\mathrm{BuLi}$ as base. $\mathrm{BuLi}(220 \mu \mathrm{L}$, $2.5 \mathrm{M}$ in hexane, $1.1 \mathrm{eq}$ ) was added to a stirred, precooled $\left(-78^{\circ} \mathrm{C}\right)$ solution of $\mathbf{5 a}(240.0 \mathrm{mg}, 0.50 \mathrm{mmol})$ in THF $(15 \mathrm{~mL})$ by syringe, and the resulting mixture was stirred at $-78^{\circ} \mathrm{C}$ for 15 min under Ar. To this solution was added benzaldehyde $(55.6 \mu \mathrm{L}, 1.1 \mathrm{eq})$ by syringe, and the resulting solution was stirred at $-78^{\circ} \mathrm{C}$ for $30 \mathrm{~min}$, and then allowed to warm to rt and stirred for $2 \mathrm{~h}$ under Ar. The reaction was quenched by the addition of $\mathrm{H}_{2} \mathrm{O}(10 \mathrm{~mL})$, and the product was extracted with $\mathrm{CH}_{2} \mathrm{Cl}_{2}(20 \mathrm{~mL})$. The organic layer was separated and the aqueous layer was extracted further with $\mathrm{CH}_{2} \mathrm{Cl}_{2}(10 \mathrm{~mL} \times 2)$. The combined organic layers were dried over $\mathrm{MgSO}_{4}$, filtered, and concentrated. The residue was purified by flash chromatography $\left(\mathrm{SiO}_{2}, \mathrm{CH}_{2} \mathrm{Cl}_{2} / \mathrm{Et}_{2} \mathrm{O}, 20 / 1\right)$ to afford 6a.1 (202.8 mg, 94\%) as a pale-yellow solid. Melting point and other spectroscopic data of this product were exactly matched with those of the same product prepared by using $\mathrm{NaH}$ as base.

Compound 6a.2: a white solid; mp 222 - $224{ }^{\circ} \mathrm{C}$; IR (KBr) $2174,1636 \mathrm{~cm}^{-1} ;{ }^{1} \mathrm{H} \mathrm{NMR}\left(\mathrm{CDCl}_{3}, 400 \mathrm{MHz}\right) \delta 2.40(\mathrm{~s}, 3 \mathrm{H})$, 7.17-7.24 (m, 3H), 7.29 (d, 1H, $J=15.6 \mathrm{~Hz}), 7.49-7.58(\mathrm{~m}, 6 \mathrm{H})$, $7.60-7.78(\mathrm{~m}, 10 \mathrm{H}), 7.79(\mathrm{~d}, 1 \mathrm{H}, J=15.6 \mathrm{~Hz}) ;{ }^{13} \mathrm{C} \mathrm{NMR}(100$ $\left.\mathrm{MHz}, \mathrm{CDCl}_{3}\right) \delta 19.87,50.16,51.44,122.04,122.20,122.71$, 123.64, 124.64, 124.73, 126.08, 126.46, 129.07, 129.11, 129.20, $130.48,133.05,133.07,133.54,133.64,134.21,136.36,136.37$, 137.63, 185.86, 185.90 .

Compound 6a.3: a white solid; mp 207 - $209{ }^{\circ} \mathrm{C}$; IR (KBr) 2174, $1636 \mathrm{~cm}^{-1}$; ${ }^{1} \mathrm{H}$ NMR $\left(\mathrm{CDCl}_{3}, 600 \mathrm{MHz}\right) \delta 2.38(\mathrm{~s}, 6 \mathrm{H})$, 7.01-7.10 (m, 3H), 7.11 (d, 1H, $J=15.8 \mathrm{~Hz}), 7.51-7.57$ (m, 6H), 
7.61-7.70 (m, 10H); ${ }^{13} \mathrm{C}$ NMR (150 MHz, $\left.\mathrm{CDCl}_{3}\right) \delta 21.30$, 50.32, 51.16, 122.05, 122.16, 122.80, 123.42, 127.51, 128.01, $129.13,129.20,129.35,129.40,133.11,133.13,133.60,133.66$, $135.04,136.85,137.08,185.93,185.95$.

Compound 6a.4: a white solid; mp 159 - $161{ }^{\circ} \mathrm{C}$; IR (KBr) $2170,1650 \mathrm{~cm}^{-1}$; ${ }^{1} \mathrm{H} \mathrm{NMR}\left(\mathrm{CDCl}_{3}, 600 \mathrm{MHz}\right) \delta 2.53,2 \mathrm{H}, J=$ $7.6 \mathrm{~Hz}), 2.77(\mathrm{t}, 2 \mathrm{H}, J=7.9 \mathrm{~Hz}), 6.80\left(\mathrm{dt}, 1 \mathrm{H}, J_{1}=15.1 \mathrm{~Hz}, J_{2}=\right.$ $6.5 \mathrm{~Hz}), 6.88(\mathrm{~d}, 1 \mathrm{H}, J=15.1 \mathrm{~Hz}), 7.15-7.29(\mathrm{~m}, 5 \mathrm{H}), 7.47-7.55$ $(\mathrm{m}, 6 \mathrm{H}), 7.58-7.67(\mathrm{~m}, 9 \mathrm{H}) ;{ }^{13} \mathrm{C}$ NMR $\left(150 \mathrm{MHz}, \mathrm{CDCl}_{3}\right) \delta$ $33.97,34.79,49.37,50.22,122.17,122.28,122.84,123.47$, $125.86,126.95,127.01,128.32,129.07,129.15,133.03,133.05$, $133.52,133.60,141.42,141.98,186.18,186.21$.

Compound 6a.5: a white solid; mp $122-124{ }^{\circ} \mathrm{C}$; IR (KBr) $2172,1649 \mathrm{~cm}^{-1} ;{ }^{1} \mathrm{H} \mathrm{NMR}\left(\mathrm{CDCl}_{3}, 600 \mathrm{MHz}\right) \delta 0.88(\mathrm{t}, 3 \mathrm{H}, J=$ $6.9 \mathrm{~Hz}), 1.20-1.35(\mathrm{~m}, 8 \mathrm{H}), 1.40-1.48(\mathrm{~m}, 2 \mathrm{H}), 2.20$ (q, $2 \mathrm{H}, J=$ $7.2 \mathrm{~Hz}), 6.74\left(\mathrm{dt}, 1 \mathrm{H}, J_{l}=15.1 \mathrm{~Hz}, J_{2}=6.9 \mathrm{~Hz}\right), 6.81(\mathrm{~d}, 1 \mathrm{H}$, $J=15.1 \mathrm{~Hz}), 7.48-7.55(\mathrm{~m}, 6 \mathrm{H}), 7.58-7.67(\mathrm{~m}, 9 \mathrm{H}) ;{ }^{13} \mathrm{C} \mathrm{NMR}$ $\left(\mathrm{CDCl}_{3}, 100 \mathrm{MHz}\right) \delta 14.04,22.58,28.44,29.05,29.23,31.71$, 32.13, 48.93, 50.20, 122.19, 122.35, 122.79, 123.73, 126.42, $126.51,129.01,129.15,132.97,133.00,133.51,133.62,143.43$, 186.47.

Compound 6a.6: a white solid; mp $174-176^{\circ} \mathrm{C}$; IR (KBr) 2174, 1708, $1654 \mathrm{~cm}^{-1} ;{ }^{1} \mathrm{H} \mathrm{NMR}\left(\mathrm{CDCl}_{3}, 400 \mathrm{MHz}\right) \delta 1.44(\mathrm{~s}$, $9 \mathrm{H}), 3.90(\mathrm{~s}, 2 \mathrm{H}), 4.81(\mathrm{~s}, 1 \mathrm{H}), 6.68\left(\mathrm{dt}, 1 \mathrm{H}, J_{1}=15.4 \mathrm{~Hz}, J_{2}=\right.$ $4.9 \mathrm{~Hz}), 6.89(\mathrm{~d}, 1 \mathrm{H}, J=15.4 \mathrm{~Hz}), 7.47-7.70(\mathrm{~m}, 15 \mathrm{H}) ;{ }^{13} \mathrm{C} \mathrm{NMR}$ $\left(\mathrm{CDCl}_{3}, 100 \mathrm{MHz}\right) \delta 28.23,41.35,49.59,50.86,79.35,121.67$, 121.83, 122.44, 123.38, 126.22, 128.97, 129.10, 129.20, 132.98, 133.01, 133.39, 135.50, 138.42, 155.55, 185.21, 185.24.

Compound 6a.7: a yellow solid; mp $214-216^{\circ} \mathrm{C}$; IR (KBr) $2173,1625 \mathrm{~cm}^{-1} ;{ }^{1} \mathrm{H} \mathrm{NMR}\left(\mathrm{CDCl}_{3}, 400 \mathrm{MHz}\right) \delta 6.79(\mathrm{~d}, 1 \mathrm{H}$, $J=15.6 \mathrm{~Hz}), 6.97\left(\mathrm{dd}, 1 \mathrm{H}, J_{I}=15.6 \mathrm{~Hz}, J_{2}=10.7 \mathrm{~Hz}\right), 7.05(\mathrm{~d}$, $1 \mathrm{H}, J=15.1 \mathrm{~Hz}), 7.22-7.37(\mathrm{~m}, 4 \mathrm{H}), 7.40-7.47$ (d, 2H, $J=7.3$ $\mathrm{Hz}), 7.48-7.56(\mathrm{~m}, 6 \mathrm{H}), 7.58-7.71(\mathrm{~m}, 9 \mathrm{H}), 7.60-7.66(\mathrm{~m}, 9 \mathrm{H})$; ${ }^{13} \mathrm{C} \mathrm{NMR}\left(\mathrm{CDCl}_{3}, 100 \mathrm{MHz}\right) \delta 50.16,51.44,122.14,122.30$, 122.71, 123.64, 126.91, 127.31, 127.49, 127.58, 128.41, 128.66, 129.08, 129.20, 133.07, 133.10, 133.55, 133.66, 136.64, 138.94, 138.96, 138.98, 185.95, 185.98 .

Compound 6a.8: a pale-brown solid; mp 180 - $225^{\circ} \mathrm{C}$ (dec.); IR (KBr) 2173, $1637 \mathrm{~cm}^{-1} ;{ }^{1} \mathrm{H}$ NMR $\left(\mathrm{CDCl}_{3}, 400 \mathrm{MHz}\right) \delta 6.42$ $\left(\mathrm{dd}, 1 \mathrm{H}, J_{l}=3.4 \mathrm{~Hz}, J_{2}=2.0 \mathrm{~Hz}\right), 6.51(\mathrm{~d}, 1 \mathrm{H}, J=3.4 \mathrm{~Hz})$, $7.27(\mathrm{~d}, 1 \mathrm{H}, J=15.6 \mathrm{~Hz}), 7.36(\mathrm{~d}, 1 \mathrm{H}, J=15.6 \mathrm{~Hz}), 7.44$ (d, $1 \mathrm{H}, J=2.0 \mathrm{~Hz}), 7.49-7.57(\mathrm{~m}, 6 \mathrm{H}), 7.60-7.70(\mathrm{~m}, 9 \mathrm{H}) ;{ }^{13} \mathrm{C}$ $\mathrm{NMR}\left(\mathrm{CDCl}_{3}, 100 \mathrm{MHz}\right) \delta 50.15,51.44,111.95,113.42,121.72$, $121.81,121.88,122.03,122.77,123.70,125.75,125.76,129.07$, 129.20, 133.04, 133.07, 133.55, 133.65, 143.87, 152.05, 185.58, 185.62 .

Compound 6a.9: a yellow solid; mp $154-156{ }^{\circ} \mathrm{C}$; IR (KBr) $2171,1627 \mathrm{~cm}^{-1} ;{ }^{1} \mathrm{H} \mathrm{NMR}\left(\mathrm{CDCl}_{3}, 400 \mathrm{MHz}\right) \delta 7.00(\mathrm{dd}, 1 \mathrm{H}$, $\left.J_{I}=5.2 \mathrm{~Hz}, J_{2}=3.4 \mathrm{~Hz}\right), 7.20(\mathrm{~d}, 1 \mathrm{H}, J=3.4 \mathrm{~Hz}), 7.25(\mathrm{~d}, 1 \mathrm{H}$, $J=15.6 \mathrm{~Hz}), 7.30(\mathrm{~d}, 1 \mathrm{H}, J=5.2 \mathrm{~Hz}), 7.48-7.57(\mathrm{~m}, 6 \mathrm{H})$, 7.58-7.72 (m, 10H); ${ }^{13} \mathrm{C} \mathrm{NMR}\left(\mathrm{CDCl}_{3}, 100 \mathrm{MHz}\right) \delta 50.05$, 51.32, 121.81, 121.97, 122.70, 122.80, 123.64,127.29, 127.74, $129.06,129.18,129.84,131.57,133.04,133.06,133.52,133.62$, $140.75,185.36,185.40$.

Compound 6a.10: a white solid; mp $188-189.5^{\circ} \mathrm{C}$; IR (KBr) $2171,1636 \mathrm{~cm}^{-1} ;{ }^{1} \mathrm{H} \mathrm{NMR}\left(\mathrm{CDCl}_{3}, 400 \mathrm{MHz}\right) \delta 0.96(\mathrm{t}, 3 \mathrm{H}, J=$ $7.3 \mathrm{~Hz}), 1.10$ (t, 3H, $J=7.3 \mathrm{~Hz}), 2.18$ (q, $2 \mathrm{H}, J=7.3 \mathrm{~Hz}), 2.54$ (q, $2 \mathrm{H}, J=7.3 \mathrm{~Hz}), 6.53(\mathrm{~s}, 1 \mathrm{H}), 7.47-7.55(\mathrm{~m}, 6 \mathrm{H}), 7.57-7.68$ $(\mathrm{m}, 9 \mathrm{H}) ;{ }^{13} \mathrm{C} \mathrm{NMR}\left(100 \mathrm{MHz}, \mathrm{CDCl}_{3}\right) \delta 12.36,13.31,24.75$, $30.69,49.47,50.75,120.08,120.17,122.41,122.58,123.23$, $124.16,128.93,129.06,132.81,132.83,133.49,133.58,160.44$, $188.74,188.78$.

Compound 6a.11: a pale-yellow solid; $\operatorname{mp} 252-253^{\circ} \mathrm{C}$; IR (KBr) 2174, $1608 \mathrm{~cm}^{-1} ;{ }^{1} \mathrm{H} \mathrm{NMR}\left(\mathrm{CDCl}_{3}, 400 \mathrm{MHz}\right) \delta 7.04(\mathrm{~s}$, 1H) $7.25-7.32(\mathrm{~m}, 10 \mathrm{H}), 7.44-7.64(\mathrm{~m}, 15 \mathrm{H}) ;{ }^{13} \mathrm{C}$ NMR $(100$ $\left.\mathrm{MHz}_{2} \mathrm{CDCl}_{3}\right) \delta 50.61,51.85,121.95,122.12,122.58,123.52$, $126.87,126.96,127.48,127.62,128.04,128.26,128.32,128.96$, $129.09,130.04,132.96,132.99,133.58,133.68,139.79,141.69$, $148.96,188.99,189.03$.

General procedure for 2 a using Pd-C (10\%)/ $\mathbf{H}_{2}$ (1 atm). A slurry of 6a.1 (216.0 mg, $0.50 \mathrm{mmol})$ and Pd-C (10\%) (21.6 mg) in a mixed solvent $(5 \mathrm{~mL}, \mathrm{THF} / \mathrm{MeOH}=1 / 1)$ was stirred for $3 \mathrm{~h}$ using balloon of $\mathrm{H}_{2}(1 \mathrm{~atm})$. The mixture was filtered, and the filtered-cake was washed with $\mathrm{THF}(5 \mathrm{~mL})$ and $\mathrm{MeOH}(5 \mathrm{~mL})$. Removal of solvent in vacuo and drying under high vacuum provided 2a.1 (212.6 mg, 98\%) as a white solid. mp $172-174{ }^{\circ} \mathrm{C}$; IR $(\mathrm{KBr}) 2172,1584 \mathrm{~cm}^{-1} ;{ }^{1} \mathrm{HNMR}\left(\mathrm{CDCl}_{3}, 400 \mathrm{MHz}\right) \delta 7.45-$ $7.70(\mathrm{~m}, 15 \mathrm{H}), 7.18-7.32(\mathrm{~m}, 5 \mathrm{H}), 3.16(\mathrm{t}, 2 \mathrm{H}, J=7.1 \mathrm{~Hz}), 3.06$ (t, $2 \mathrm{H}, J=7.1 \mathrm{~Hz}) ;{ }^{13} \mathrm{C} \mathrm{NMR}\left(100 \mathrm{MHz}, \mathrm{CDCl}_{3}\right) \delta 31.16,40.41$, $40.48,48.12$, 49.38, 122.49, 122.65, 122.77, 123.70, 125.75, 128.23, 128.69, 129.01, 129.14, 132.96, 132.99, 133.49, 133.59, 141.53, 195.86, 195.89; HR-MS (EI) calcd for $\mathrm{C}_{29} \mathrm{H}_{24} \mathrm{NOP}$ 433.1596, found 433.1596 .

Compound 2a.2: a white solid; mp $161-162{ }^{\circ} \mathrm{C}$; IR (KBr) $2170,1579 \mathrm{~cm}^{-1}$; ${ }^{1} \mathrm{H} \mathrm{NMR}\left(\mathrm{CDCl}_{3}, 400 \mathrm{MHz}\right) \delta 2.35(\mathrm{~s}, 3 \mathrm{H})$, $2.98(\mathrm{~s}, 4 \mathrm{H}), 7.08-7.25(\mathrm{~m}, 4 \mathrm{H}), 7.46-7.72(\mathrm{~m}, 15 \mathrm{H}) ;{ }^{13} \mathrm{C} \mathrm{NMR}$ $\left(100 \mathrm{MHz}, \mathrm{CDCl}_{3}\right) \delta 19.40,28.65,39.41,39.48,48.11,49.37$, $122.39,122.55,122.67,123.60,125.80,125.90,128.96,129.01$, $129.09,129.14,129.21,130.06,133.00,133.03,133.48,133.58$, 133.66, 136.24, 139.56, 196.05, 196.08 .

Compound 2a.3: a white solid; mp 206 - $207{ }^{\circ} \mathrm{C}$; IR (KBr) $2173,1581 \mathrm{~cm}^{-1} ;{ }^{1} \mathrm{H} \mathrm{NMR}\left(\mathrm{CDCl}_{3}, 400 \mathrm{MHz}\right) \delta 2.37(\mathrm{~s}, 6 \mathrm{H})$, $2.83(\mathrm{t}, 2 \mathrm{H}, J=8.3 \mathrm{~Hz}), 2.99(\mathrm{t}, 2 \mathrm{H}, J=8.3 \mathrm{~Hz}), 7.00(\mathrm{~s}, 3 \mathrm{H})$, 7.49-7.68 (m, 15H); ${ }^{13} \mathrm{C}$ NMR $\left(100 \mathrm{MHz}, \mathrm{CDCl}_{3}\right) \delta 19.87$, $25.93,38.73,38.80,47.67,48.92,122.84,123.78,125.75$, $128.08,129.07,129.20,133.06,133.09,133.55,133.66,136.45$, $138.18,196.42,196.45$

Compound 2a.4: an off-white solid; mp $126-128^{\circ} \mathrm{C}$; IR (KBr) $2169,1592 \mathrm{~cm}^{-1} ;{ }^{1} \mathrm{H} \mathrm{NMR}\left(\mathrm{CDCl}_{3}, 400 \mathrm{MHz}\right) \delta 1.62-1.78(\mathrm{~m}$, $4 \mathrm{H}), 2.63(\mathrm{t}, 2 \mathrm{H}, J=7.6 \mathrm{~Hz}), 2.76(\mathrm{t}, 2 \mathrm{H}, J=7.6 \mathrm{~Hz}), 7.14-7.29$ $(\mathrm{m}, 5 \mathrm{H}), 7.48-7.54(\mathrm{~m}, 6 \mathrm{H}), 7.56-7.65(\mathrm{~m}, 9 \mathrm{H}) ;{ }^{13} \mathrm{C} \mathrm{NMR}$ $\left(150 \mathrm{MHz} \mathrm{CDCl}_{3}\right) \delta 25.21,31.06,31.20,35.57,35.75,35.93$, $39.19,39.24,48.14,48.98,122.66,122.77,122.95,123.56$, $125.31,125.34,125.65,128.00,128.04,128.22,128.25,128.30$, $128.53,128.92,129.01,129.11,129.19,132.97,133.03,133.40$, 133.42, 133.47, 133.53, 133.59, 142.63, 197.14, 197.18

Compound 2a.5: a white solid; mp $116-117^{\circ} \mathrm{C}$; IR (KBr) $2173,1582 \mathrm{~cm}^{-1} ;{ }^{1} \mathrm{H} \mathrm{NMR}\left(\mathrm{CDCl}_{3}, 600 \mathrm{MHz}\right) \delta 0.87(\mathrm{t}, 3 \mathrm{H}, J=$ $6.9 \mathrm{~Hz}) 1.09-1.38(\mathrm{~m}, \mathrm{H}), 1.66(\mathrm{q}, 2 \mathrm{H}, J=7.6 \mathrm{~Hz}), 2.69(\mathrm{t}, 2 \mathrm{H}$, $J=7.6 \mathrm{~Hz}), 7.48-7.53(\mathrm{~m}, 6 \mathrm{H}), 7,56-7.67(\mathrm{~m}, 9 \mathrm{H}) ;{ }^{13} \mathrm{C} \mathrm{NMR}$ $\left(150 \mathrm{MHz}, \mathrm{CDCl}_{3}\right) \delta 14.08,22.63,25.58,29.25,29.37,29.45$, $29.50,31.85,39.52,39.56,48.05,48.89,123.02,123.64$, 128.99, 129.08, 132.96, 132.97, 133.48, 133.55, 197.61, 197.63.

Compound 2a.6: a white solid; mp $157-159{ }^{\circ} \mathrm{C}$; IR (KBr) 2171, 1681, $1598 \mathrm{~cm}^{-1} ;{ }^{1} \mathrm{H} \mathrm{NMR}\left(\mathrm{CDCl}_{3}, 400 \mathrm{MHz}\right) \delta 1.43(\mathrm{~s}$, 9H), 1.84 (q, 2H, $J=7.3 \mathrm{~Hz}), 2.74$ (t, 2H, $J=7.3 \mathrm{~Hz}), 3.15$ (d, 
$2 \mathrm{H}, J=6.3 \mathrm{~Hz}), 7.46-7.70(\mathrm{~m}, 15 \mathrm{H}) ;{ }^{13} \mathrm{C}$ NMR $(150 \mathrm{MHz}$, $\left.\mathrm{CDCl}_{3}\right) \delta 25.34,28.39,36.65,36.69,40.13,48.16,48.99$, $78.79,122.42,122.53,122.76,123.38,129.08,129.16,133.09$, $133.45,133.52,155.93,196.27,196.29$.

Compound 2a.7: a white solid; mp 152 - $154{ }^{\circ} \mathrm{C}$; IR (KBr) $2172,1580 \mathrm{~cm}^{-1} ;{ }^{1} \mathrm{HNMR}\left(\mathrm{CDCl}_{3}, 600 \mathrm{MHz}\right) \delta 3.00(\mathrm{t}, 2 \mathrm{H}, J=$ $7.2 \mathrm{~Hz}), 3.08$ (t, $2 \mathrm{H}, J=7.2 \mathrm{~Hz}), 6.05$ (d, $1 \mathrm{H}, J=3.4 \mathrm{~Hz}), 6.29$ $(\mathrm{t}, 1 \mathrm{H}, J=2.4 \mathrm{~Hz}), 7.32(\mathrm{~d}, 1 \mathrm{H}, J=2.1 \mathrm{~Hz}), 7.48-7.53(\mathrm{~m}, 6 \mathrm{H})$, 7.54-7.65 (m, 9H); ${ }^{13} \mathrm{C}$ NMR $\left(100 \mathrm{MHz}, \mathrm{CDCl}_{3}\right) \delta 23.44$, $37.15,37.22$, 47.96, 49.22, 105.03, 109.96, 122.33, 122.49, $122.66,123.59,128.99,129.11,133.01,133.46,133.56,140.80$, $155.34,195.20$.

Compound 2a.8: a white solid; mp $125-127{ }^{\circ} \mathrm{C}$; IR (KBr) $2173,1580 \mathrm{~cm}^{-1} ;{ }^{1} \mathrm{H} \mathrm{NMR}\left(\mathrm{CDCl}_{3}, 400 \mathrm{MHz}\right) \delta 0.88(\mathrm{t}, 6 \mathrm{H}, J=$ $7.6 \mathrm{~Hz}), 1.28-1.41(\mathrm{~m}, 4 \mathrm{H}), 1.87(\mathrm{q}, 1 \mathrm{H}, J=6.3 \mathrm{~Hz}), 2.61(\mathrm{~d}$, $2 \mathrm{H}, J=6.8 \mathrm{~Hz}), 7.47-7.54(\mathrm{~m}, 6 \mathrm{H}), 7.57-7.65(\mathrm{~m}, 9 \mathrm{H}) ;{ }^{13} \mathrm{C}$ NMR $\left(100 \mathrm{MHz}, \mathrm{CDCl}_{3}\right) \delta 10.86,25.72,37.97,43.28,43.35$, 48.85, 50.11, 122.69, 122.86, 122.99, 123.92, 128.94, 129.07, $132.92,132.95,133.48,133.58,197.46,197.49$.

Compound 2a.9: a white solid; mp $195-197^{\circ} \mathrm{C}$; IR (KBr) $2176,1578 \mathrm{~cm}^{-1} ;{ }^{1} \mathrm{H}$ NMR $\left(\mathrm{CDCl}_{3}, 600 \mathrm{MHz}\right) \delta 3.45(\mathrm{~d}, 2 \mathrm{H}$, $J=7.8 \mathrm{~Hz}), 4.70(\mathrm{t}, 1 \mathrm{H}, J=7.8 \mathrm{~Hz}), 7.17-7.64(\mathrm{~m}, 25 \mathrm{H}) ;{ }^{13} \mathrm{C}$ NMR (150 MHz, $\left.\mathrm{CDCl}_{3}\right) \delta 44.48,44.52,47.36,47.47,49.82$, $50.65,122.41,122.55,123.17,125.96,126.27,127.98,128.23$, 128.52, 128.86, 128.94, 129.10, 129.18, 132.80, 132.94, 133.20, 133.28, 133.47, 133.54, 144.01, 194.41, 194.43.

Synthesis of HWE Reagent $5 \mathrm{~b}$ from diethylphosphonoacetic acid (9). To a stirred solution of diethylphosphonoacetic acid (1.42 g, 95\%, $6.88 \mathrm{mmol}$ ) and (tert-butoxycarbonylmethylene) triphenylphosphorane $(2.64 \mathrm{~g}, 98 \%)$ in dry $\mathrm{CH}_{2} \mathrm{Cl}_{2}(30 \mathrm{~mL})$ were added EDC (1.35 g, 98\%) and DMAP (85.0 mg, 99\%), and the resulting mixture was stirred at $\mathrm{rt}$ for $12 \mathrm{~h}$ under Ar. The reaction was quenched by the addition of water $(20 \mathrm{~mL})$, and the organic layer was separated. The aqueous layer was extracted further with $\mathrm{CH}_{2} \mathrm{Cl}_{2}(10 \mathrm{~mL} \times 2)$, and the combined organic layers were dried over $\mathrm{MgSO}_{4}$, filtered, and concentrated. The solid residue was purified by flash chromatography $\left(\mathrm{SiO}_{2}, \mathrm{CH}_{2} \mathrm{Cl}_{2} / \mathrm{MeOH}=20 / 1\right)$ to provide $\mathbf{5 b}(3.29 \mathrm{~g}, 86 \%)$ as a white solid. mp $135-137^{\circ} \mathrm{C}$; IR (KBr) 3053, 2984, 1669, $1542,1251 \mathrm{~cm}^{-1}$; ${ }^{1} \mathrm{H} \mathrm{NMR}\left(\mathrm{CDCl}_{3}, 400 \mathrm{MHz}\right) \delta 1.04(\mathrm{~s}, 9 \mathrm{H})$, $1.24(\mathrm{t}, 6 \mathrm{H}, J=7.1 \mathrm{~Hz}), 3.82(\mathrm{~d}, 2 \mathrm{H}, J=21.9 \mathrm{~Hz}), 4.04(\mathrm{~m}$, 4H), 7.41-7.56 (m, 9H), 7.70-7.79 (m, 6H); ${ }^{13} \mathrm{C} \mathrm{NMR}\left(\mathrm{CDCl}_{3}\right.$, $100 \mathrm{MHz}) \delta 16.28,16.34,27.98,37.41,37.48 .38 .67,38.75$, 61.60, 78.90, 126.13, 127.06, 128.34, 128.47, 131.47, 131.49, 133.08,133.18, 166.92, 167.04, 186.73, 186.80, 186.86; MS (ESI) $m / z(\%) 577[\mathrm{M}+\mathrm{Na}]^{+}$(100), 561 (14), 481 (21), 477 (13), 459 (14), 455 (13), 361 (15), 360 (62); HR-MS (ESI) calcd for $\mathrm{C}_{30} \mathrm{H}_{36} \mathrm{NaO}_{6} \mathrm{P}_{2}$ 577.1885, found 577.1885; Anal. calcd for $\mathrm{C}_{30} \mathrm{H}_{36} \mathrm{O}_{6} \mathrm{P}_{2}$ : C, 64.98; $\mathrm{H}, 6.54$. found: $\mathrm{C}, 64.71 ; \mathrm{H}$, 6.50 .

General procedure for $6 \mathrm{~b}$ using $\mathbf{N a H}$ as base. $\mathrm{NaH}(26.0 \mathrm{mg}$, $60 \%$ in oil, $1.3 \mathrm{eq})$ was added to a stirred solution of $\mathbf{5 b}(277.3$ $\mathrm{mg}, 0.50 \mathrm{mmol})$ in THF $(10 \mathrm{~mL})$, and the resulting slurry was stirred at $\mathrm{rt}$ for $20 \mathrm{~min}$, and then at $0{ }^{\circ} \mathrm{C}$ for $20 \mathrm{~min}$ under $\mathrm{Ar}$. To this mixture was added benzaldehyde $(50.8 \mu \mathrm{L}, 1.0 \mathrm{eq})$ by syringe, and the resulting mixture was stirred at $0{ }^{\circ} \mathrm{C}$ for $30 \mathrm{~min}$, and then at $\mathrm{rt}$ for $1 \mathrm{~h}$ under Ar. The reaction was quenched by the addition of $\mathrm{H}_{2} \mathrm{O}(10 \mathrm{~mL})$, and the product was extracted with $\mathrm{CH}_{2} \mathrm{Cl}_{2}(20 \mathrm{~mL})$. The aqueous layer was extracted further with $\mathrm{CH}_{2} \mathrm{Cl}_{2}(10 \mathrm{~mL} \times 2)$. The combined organic layers were dried over $\mathrm{MgSO}_{4}$, filtered, and concentrated. The residue was purified by flash chromatography $\left(\mathrm{SiO}_{2}, \mathrm{CH}_{2} \mathrm{Cl}_{2} / \mathrm{Et}_{2} \mathrm{O}, 20 / 1\right)$ to afford 6b.1 (225.4 mg, 89\%) as an off-white solid; mp 178 $179.5{ }^{\circ} \mathrm{C}$; IR (KBr) 1649, $1547 \mathrm{~cm}^{-1}$; ${ }^{1} \mathrm{H}$ NMR $\left(\mathrm{CDCl}_{3}, 600\right.$ MHz) $\delta 1.09$ (s, 9H), 7.22-7.32 (m, 3H), 7.39-7.59 (m, 12H), 7.68-7.76 (m, 6H), $8.20(\mathrm{~d}, 1 \mathrm{H}, J=15.8 \mathrm{~Hz}) ;{ }^{13} \mathrm{C} \mathrm{NMR}\left(\mathrm{CDCl}_{3}\right.$, $150 \mathrm{MHz}) \delta 28.13,78.85,126.26,126.32,126.79,127.41$, $127.97,128.40,128.47,128.56,131.42,132.93,132.99,136.59$, 137.22, 166.99, 167.08, 185.87, 185.89 .

General procedure for $\mathbf{6 b}$ using $\mathrm{BuLi}$ as base. $\mathrm{BuLi}(220 \mu \mathrm{L}$, $2.5 \mathrm{M}$ in hexane, $1.1 \mathrm{eq})$ was added to a stirred, precooled ( -78 $\left.{ }^{\circ} \mathrm{C}\right)$ solution of $\mathbf{5 b}(277.3 \mathrm{mg}, 0.50 \mathrm{mmol})$ in THF $(10 \mathrm{~mL})$ by syringe, and the resulting mixture was stirred at $-78^{\circ} \mathrm{C}$ for 15 min under Ar. To this solution was added benzaldehyde $(55.9 \mu \mathrm{L}$, 1.1 eq) by syringe, and the resulting solution was stirred at $-78{ }^{\circ} \mathrm{C}$ for $30 \mathrm{~min}$, and then allowed to warm to rt for $2 \mathrm{~h}$ under Ar. The reaction was quenched by the addition of $\mathrm{H}_{2} \mathrm{O}(10 \mathrm{~mL})$, and the product was extracted with $\mathrm{CH}_{2} \mathrm{Cl}_{2}(20 \mathrm{~mL})$. The organic layer was separated and the aqueous layer was extracted further with $\mathrm{CH}_{2} \mathrm{Cl}_{2}(10 \mathrm{~mL} \times 2)$. The combined organic layers were dried over $\mathrm{MgSO}_{4}$, filtered, and concentrated. The residue was purified by flash chromatography $\left(\mathrm{SiO}_{2}, \mathrm{CH}_{2} \mathrm{Cl}_{2} / \mathrm{Et}_{2} \mathrm{O}\right.$, 20/1) to afford 6b.1 (239 mg, 94\%) as an off-white solid. Melting point and other spectroscopic data of this product were exactly matched with those of the same product prepared by using $\mathrm{NaH}$ as base.

Compound 6b.2: a white solid; $\mathrm{mp} 77-79^{\circ} \mathrm{C}$; IR (KBr) 1661, $1525 \mathrm{~cm}^{-1} ;{ }^{1} \mathrm{H} \mathrm{NMR}\left(\mathrm{CDCl}_{3}, 600 \mathrm{MHz}\right) \delta 0.87$ (t, 3H, $J=6.9$ $\mathrm{Hz}), 1.06$ (s, 9H), 1.20-1.32 (m, 8H), 1.38-1.47 (m, 2H), 2.18 $(\mathrm{q}, 2 \mathrm{H}, J=6.9 \mathrm{~Hz}), 6.65\left(\mathrm{dt}, 1 \mathrm{H}, J_{I}=15.1 \mathrm{~Hz}, J_{2}=7.0 \mathrm{~Hz}\right)$, 7.37-7.52 (m, 10H), 7.63-7.74 (m, 6H); ${ }^{13} \mathrm{C} \mathrm{NMR}\left(\mathrm{CDCl}_{3}\right.$, $150 \mathrm{MHz}) \delta 14.08,22.62,28.07,28.68,29.13,29.34,31.77$, $32.46,78.67,126.98,127.60,128.41,131.31,132.91,132.97$, 141.41, 166.99, 167.07, 186.57.

Compound 6b.3: a white solid; mp $124-126{ }^{\circ} \mathrm{C}$; IR (KBr) 1697, 1661, $1507 \mathrm{~cm}^{-1} ;{ }^{1} \mathrm{H}$ NMR $\left(\mathrm{CDCl}_{3}, 600 \mathrm{MHz}\right) \delta 1.06(\mathrm{~s}$, $9 \mathrm{H}), 1.43(\mathrm{~s}, 9 \mathrm{H}), 3.90(\mathrm{~s}, 2 \mathrm{H}), 4.68(\mathrm{~s}, 1 \mathrm{H}), 6.53\left(\mathrm{dt}, 1 \mathrm{H}, J_{l}=\right.$ $\left.15.8 \mathrm{~Hz}, J_{2}=5.2 \mathrm{~Hz}\right), 7.40-7.54(\mathrm{~m}, 10 \mathrm{H}), 7.65-7.72(\mathrm{~m}, 6 \mathrm{H})$; ${ }^{13} \mathrm{C} \mathrm{NMR}\left(\mathrm{CDCl}_{3}, 150 \mathrm{MHz}\right) \delta 28.05,28.35,41.92,78.89$, 79.16, 126.53, 127.15, 128.46, 128.54, 129.32, 131.48, 132.93, $132.98,133.07,135.85,155.63,166.95,167.03,185.58$.

Compound 6b.4: a yellow solid; mp $94-96{ }^{\circ} \mathrm{C}$; IR (KBr) $1658,1520 \mathrm{~cm}^{-1} ;{ }^{1} \mathrm{H} \mathrm{NMR}\left(\mathrm{CDCl}_{3}, 600 \mathrm{MHz}\right) \delta 1.06(\mathrm{~s}, 9 \mathrm{H})$, $6.69(\mathrm{~d}, 1 \mathrm{H}, J=15.8 \mathrm{~Hz}), 7.02\left(\mathrm{dd}, 1 \mathrm{H}, J_{1}=15.8 \mathrm{~Hz}, J_{2}=11.3\right.$ $\mathrm{Hz}), 7.18-7.32(\mathrm{~m}, 4 \mathrm{H}), 7.37-7.52(\mathrm{~m}, 11 \mathrm{H}), 7.67-7.77(\mathrm{~m}$, $7 \mathrm{H}) ;{ }^{13} \mathrm{C} \mathrm{NMR}\left(\mathrm{CDCl}_{3}, 150 \mathrm{MHz}\right) \delta 28.09,78.84,126.70$, $126.82,127.44,127.91,128.47,128.56,128.68,130.32,130.38$, $131.43,132.92$, 132.98, 136.97, 137.12, 137.53, 167.05, 167.14, $186.12,186.15$.

Compound 6b.5: a white solid; mp $200-210{ }^{\circ} \mathrm{C}$ (dec.); IR (KBr) 1652, $1513 \mathrm{~cm}^{-1} ;{ }^{1} \mathrm{H} \mathrm{NMR}\left(\mathrm{CDCl}_{3}, 600 \mathrm{MHz}\right) \delta 1.10(\mathrm{~s}$, 9H), 6.30 (t, 1H, $J=2.4 \mathrm{~Hz}), 6.41(\mathrm{~d}, 1 \mathrm{H}, J=3.4 \mathrm{~Hz}), 7.20$ (d, $1 \mathrm{H}, J=15.8 \mathrm{~Hz}), 7.38-7.53(\mathrm{~m}, 10 \mathrm{H}), 7.67-7.75(\mathrm{~m}, 6 \mathrm{H}), 8.04$ $(\mathrm{d}, 1 \mathrm{H}, J=15.8 \mathrm{~Hz}) ;{ }^{13} \mathrm{C} \mathrm{NMR}\left(\mathrm{CDCl}_{3}, 150 \mathrm{MHz}\right) \delta 28.09$, 78.88, 111.64, 111.99, 124.46, 126.72, 127.34, 128.45, 128.53, 131.42 , 132.94, 132.99, 143.11, 143.14, 153.05, 166.86, 166.95, 
185.49 .

Compound 6b.6: a white solid; mp $189-190{ }^{\circ} \mathrm{C}$; IR (KBr) $1655,1508 \mathrm{~cm}^{-1} ;{ }^{1} \mathrm{H} \mathrm{NMR}\left(\mathrm{CDCl}_{3}, 600 \mathrm{MHz}\right) \delta 1.15(\mathrm{~s}, 9 \mathrm{H})$, $6.95(\mathrm{t}, 1 \mathrm{H}, J=4.5 \mathrm{~Hz}), 7.11(\mathrm{~d}, 1 \mathrm{H}, J=3.4 \mathrm{~Hz}), 7.21(\mathrm{~d}, 1 \mathrm{H}$, $J=4.8 \mathrm{~Hz}), 7.40-7.56(\mathrm{~m}, 10 \mathrm{H}), 7.68-7.75(\mathrm{~m}, 6 \mathrm{H}), 7.98(\mathrm{~d}$, $1 \mathrm{H}, J=15.1 \mathrm{~Hz}) ;{ }^{13} \mathrm{C} \mathrm{NMR}\left(\mathrm{CDCl}_{3}, 150 \mathrm{MHz}\right) \delta 28.20,78.95$, $125.64,125.70,126.11,126.66,127.28,127.56,128.46,128.55$, $128.81,130.04,131.44,131.46,132.94,133.00,142.21,166.88$, $166.97,185.10,185.13$.

General procedure for $2 \mathrm{~b}$ using $\mathrm{Pd}-\mathrm{C}(\mathbf{1 0} \%) / \mathrm{H}_{\mathbf{2}}$ (1 $\left.\mathbf{~ a t m}\right)$. A slurry of 6b.1 (253.3 mg, $0.50 \mathrm{mmol}$ ) and Pd-C (10\%) (38.0 mg, $15 \mathrm{wt} \%)$ in a mixed solvent $(5 \mathrm{~mL}, \mathrm{THF} / \mathrm{MeOH}=1 / 1)$ was stirred for $3 \mathrm{~h}$ using balloon of $\mathrm{H}_{2}$ (1 atm). The mixture was filtered, and the filtered-cake was washed with THF $(5 \mathrm{~mL})$ and $\mathrm{MeOH}(5 \mathrm{~mL})$. Removal of solvent in vacuo and drying the residue under high vacuum provided 2 b.1 (249.2 mg, 98\%) as a white solid. mp $160-162{ }^{\circ} \mathrm{C}$; IR (KBr) $1653,1550 \mathrm{~cm}^{-1}$; ${ }^{1} \mathrm{H} \mathrm{NMR}\left(\mathrm{CDCl}_{3}, 600 \mathrm{MHz}\right) \delta 1.04(\mathrm{~s}, 9 \mathrm{H}), 2.92(\mathrm{t}, 2 \mathrm{H}, J=7.6$ $\mathrm{Hz}), 3.24$ (t, 2H, $J=7.6 \mathrm{~Hz}), 7.12-7.25(\mathrm{~m}, 5 \mathrm{H}), 7.39-7.45$ (m, $6 \mathrm{H}), 7.47-7.52(\mathrm{~m}, 3 \mathrm{H}), 7.61-7.68(\mathrm{~m}, 6 \mathrm{H}) ;{ }^{13} \mathrm{C} \mathrm{NMR}(150 \mathrm{MHz}$, $\left.\mathrm{CDCl}_{3}\right) \delta 28.05,31.58,40.96,78.42,125.27,126.80,127.41$, $128.00,128.37,128.46128 .69,131.31,131.33,132.88,132.95$, $142.69,167.11,167.119,196.27$

Compound 2b.2: a colorless liquid; IR (neat) $1665,1550 \mathrm{~cm}^{-1}$; ${ }^{1} \mathrm{H} \mathrm{NMR}\left(\mathrm{CDCl}_{3}, 600 \mathrm{MHz}\right) \delta 0.87(\mathrm{t}, 3 \mathrm{H}, J=7.2 \mathrm{~Hz}), 1.06$ $(\mathrm{s}, 9 \mathrm{H}), 1.18-1.33(\mathrm{~m}, 12 \mathrm{H}), 1.58(\mathrm{q}, 2 \mathrm{H}, J=7.6 \mathrm{~Hz}), 2.85$ (t, $2 \mathrm{H}, J=7.6 \mathrm{~Hz}), 7.39-7.44(\mathrm{~m}, 6 \mathrm{H}), 7.46-7.50(\mathrm{~m}, 3 \mathrm{H}), 7.65-$ $7.71(\mathrm{~m}, 6 \mathrm{H}) ;{ }^{13} \mathrm{C} \mathrm{NMR}\left(150 \mathrm{MHz}, \mathrm{CDCl}_{3}\right) \delta 14.06,22.61$, 25.82, 28.04, 29.25, 29.55, 29.58, 29.61, 31.85, 39.88, 39.92, $78.26,126.97,127.59,128.28,128.37,131.20,131.22,132.81$, $132.87,167.16,167.24,197.73$.

Compound 2b.3: a white solid foam; $m p 46-48{ }^{\circ} \mathrm{C}$; IR (KBr) $1708,1661,1542 \mathrm{~cm}^{-1} ;{ }^{1} \mathrm{H} \mathrm{NMR}\left(\mathrm{CDCl}_{3}, 600 \mathrm{MHz}\right) \delta 1.04$ (s, $9 \mathrm{H}), 1.41$ (s, 9H), 1.78 (t, 2H, $J=6.5 \mathrm{~Hz}), 2.91$ (t, 2H, $J=6.9$ $\mathrm{Hz}), 3.09$ (q, 2H, $J=6.2 \mathrm{~Hz}), 5.14(\mathrm{~s}, 1 \mathrm{H}), 7.38-7.55(\mathrm{~m}, 9 \mathrm{H})$, $7.62-7.72(\mathrm{~m}, 6 \mathrm{H}) ;{ }^{13} \mathrm{C} \mathrm{NMR}\left(\mathrm{CDCl}_{3}, 150 \mathrm{MHz}\right) \delta 25.66,28.04$, $28.42,37.11,40.27,78.42,78.68,126.66,127.27,128.43$, 128.51, 131.45, 132.85, 132.92, 156.08, 167.30, 167.39, 196.74.

Compound 2b.4: a white solid; mp $163-164{ }^{\circ} \mathrm{C}$; IR (KBr) $1655,1550 \mathrm{~cm}^{-1} ;{ }^{1} \mathrm{H} \mathrm{NMR}\left(\mathrm{CDCl}_{3}, 600 \mathrm{MHz}\right) \delta 1.06(\mathrm{~s}, 9 \mathrm{H})$, $2.92(\mathrm{t}, 2 \mathrm{H}, J=7.6 \mathrm{~Hz}), 3.24(\mathrm{t}, 2 \mathrm{H}, J=7.6 \mathrm{~Hz}), 5.95(\mathrm{~d}, 1 \mathrm{H}$, $J=2.7 \mathrm{~Hz}), 6.23(\mathrm{t}, 1 \mathrm{H}, J=2.4 \mathrm{~Hz}), 7.26(\mathrm{~d}, 1 \mathrm{H}, J=2.1 \mathrm{~Hz})$, 7.39-7.45 (m, 6H), 7.47-7.51 (m, 3H), 7.62-7.69 (m, 6H); ${ }^{13} \mathrm{C}$ NMR $\left(150 \mathrm{MHz}, \mathrm{CDCl}_{3}\right) \delta 23.78,28.07,37.93,78.49,104.59$, $104.61,109.87,109.89,126.70,127.33,128.38,128.46,131.35$, $131.37,132.87,132.94,140.37,140.39,156.56,167.13,167.21$, 195.56.

\section{Conclusion}

In conclusion, we have developed a new synthetic approach for triphenylphosphorane ylide precursors to $\alpha$-keto amide/ester and vicinal tricarbonyl units using new HWE reagents 5 as the key reagents. Considering several advantages of this new approach: (i) new HWE reagents $\mathbf{5}$ are easy to make in one step in good yields, and also stable solids to handle; (ii) easy preparation of both triphenylphosphorane ylide precursors directly from carbonyl compounds under mild reaction conditions in good to excellent yields, this new approach could be a method of choice for the preparation of triphenylphosphorane ylide precursors $(6,2)$ to $\alpha$-keto amide/ester and vicinal tricarbonyl units.

Acknowledgments. The author would like to thank Prof. Yong Hae Kim at KAIST for helpful discussions and encouragements for this project. Financial support from Woosuk University through academic research fund (2010) is gratefully acknowledged.

\section{References}

1. (a) Otto, H. H.; Schirmeister, T. Chem. Rev. 1997, 97, 133. (b) Babine, R. E.; Bender, S. L. Chem. Rev. 1997, 97, 1359.

2. (a) Schoenberg, A.; Singer, E. Tetrahedron 1978, 34, 1285. (b) Rubin, M. B. Chem. Rev. 1975, 75, 177.

3. (a) Nakatsuka, M.; Ragan, J. A.; Sammakia, T.; Smith, D. B.; Uehling, D. E.; Schreiber, S. L. J. Am. Chem. Soc. 1990, 112, 5583. (b) Findlay, J. A.; Liu, J.-S.; Burnell, D.; Nakashima, T. Can. J. Chem. 1982, 60, 2046. (c) Fusetani, N.; Matsunaga, S.; Matsumoto, H.; Takebayashi, Y.J. Am. Chem. Soc. 1990, 112, 7053. (d) Toda, S.; Kotake, C.; Tsuno, T.; Narita, Y.; Yamasaki, T.; Konishi, M. J. Antibiot. 1992, 45, 1580.

4. Wasserman, H. H.; Kuo, G.-H. Tetrahedron 1992, 48, 7071 and other important references cited therein.

5. (a) Harbeson, S. L.; Abelleria, S. M.; Akiyama, A.; Barrett, R.; Carroll, R. M.; Straub, J. A.; Tkacz, J. N.; Wu, C.; Mosso, G. F. J. Med. Chem. 1994, 37, 2918. (b) Harvey, A. J.; Abell, A. D. Tetrahedron 2000, 56, 9763. (c) Kokotos, G.; Kotsovolou, S.; Constantinou-Kokotou, V.; Beltzner, C. C.; Dennis, E. A. J. Med. Chem. 2002, 45, 2891.

6. (a) Angelastro, M. R.; Peet, N. P.; Bey, P. J. Org. Chem. 1989, 54, 3913. (b) Ocain, T. D.; Rich, D. H. J. Med. Chem. 1992, 35, 451. (c) Wipf, P.; Kim, H-Y. J. Org. Chem. 1993, 58, 5592. (d) Yang, Z.; Zhang, Z.; Meanwell, N. A.; Kadow, J. F.; Wang, T. Org. Lett. 2002, 7, 10245. (e) Chen, J. J.; Deshpande, S. V. Tetrahedron Lett. 2003, 44, 8873. (f) Ma, M.; Li, C.; Peng, L.; Xie, F.; Zhang, X.; Wang, J. Tetrahedron Lett. 2005, 46, 3927. (g) Song, B.; Wang, S.; Sun, C.; Deng, H.; Xu, B. Tetrahedron Lett. 2007, 48,8982 .

7. (a) Schank, K.; Lick, C. Synthesis 1983, 392. (b) Detering, J.; Martin, H.-D. Angew. Chem., Int. Ed. Engl. 1988, 27, 695. (c) Hoffman, R. V.; Wilson, A. L.; Kim, H.-O. J. Org. Chem. 1990, 55, 1267. (d) Saba, A. Synth. Commun. 1994, 24, 695. (e) Inokuchi, T.; Liu, P.; Torii, S. Chem. Lett. 1994, 1411.

8. (a) Wasserman, H. H.; Ho, W.-B. J. Org. Chem. 1994, 59, 4364. (b) Wasserman, H. H.; Ennis, D. S.; Blum, C. A.; Rotello, V. M. Tetrahedron Lett. 1992, 33, 6003.

9. (a) Wasserman, H. H.; Baldino, C. M.; Coats, S. J. J. Org. Chem. 1995, 60, 8231. (b) Wasserman, H. H.; Chen, J.-H.; Xia, M. J. Am. Chem. Soc. 1999, 121, 1401. (c) Wasserman, H. H.; Lee, K.; Xia, M. Tetrahedron Lett. 2000, 41, 2511. (d) Wasserman, H. H.; Zhang, R. Tetrahedron 2002, 58, 6277. (e) Lee, K. Bull. Korean Chem. Soc. 2002, 23, 351. (f) Haberhauer, G. Synlett 2004, 1003. (g) Price, W. S.; Fletcher, S.; Jorgensen, M. R.; Miller, A. D. Synlett 2006, 1933

10. Boutagy, J.; Thomas, R. Chem. Rev. 1974, 74, 87.

11. Lee, K. Bull. Korean Chem. Soc. 2007, 28, 1641.

12. Lee, K. Bull. Korean Chem. Soc. 2009, 30, 2521.

13. Listvan, V. N.; Dombrovskii, A. V. Z. Obs. Khim. 1968, 38, 610.

14. (a) Liu, K.-G.; Yan, S.; Wu, Y.-L.; Yao, Z.-J. J. Org. Chem. 2002, 67, 6758. (b) Liu, K.-G.; Yan, S.; Wu, Y.-L.; Yao, Z.-J. Org. Lett. 2004, 6, 2269. 